\title{
Adapting to a market economy: short-term benefits and long-term costs of cashmere wool production in the Aru Basin, Tibet
}

\section{Marius Warg Nass ${ }^{1}$}

\begin{abstract}
The nomads in the northwestern parts of Tibet rely on sheep, goats and yaks for making a living. Today goats are mainly kept for surplus purposes, while sheep and yak are kept for subsistence purposes. The implementation of the new economic reform policy in Tibet Autonomous Region (TAR) by the end of the Cultural Revolution brought the nomads in TAR closer to a market economy, and the Aru nomads are now dependent on a production that both can create a surplus to provide them with a cash income and a production that can provide them with subsistence goods. This change has resulted in a change of herd and sex composition in the nomads' herds, of importance being a larger number of goats, and a larger number of male animals. The increasing importance of cashmere wool can be viewed as giving the Aru nomads new opportunities instead of decreasing their choices. However, this change in economic patterns can have long-term negative consequences for the pastoral system, where an increase in goat numbers might exacerbate rangeland degradation and a decrease in number of female animals in herds might have consequences for the growth potential of the herds. Consequently, herds with large proportions of adult male animals will be more affected by climatic perturbations, and the recuperation potential for herds will be decreased.
\end{abstract}

Keywords: Chang Tang (Tib.: byang thang), China, cashmere wool, production, nomadic pastoralism, risk, overgrazing, goats.

\footnotetext{
${ }^{1}$ Author's contact data: Norwegian Institute for Cultural Heritage Research (NIKU), High North Department, Fram Centre, N-9296 Tromsø, Norway. E-Mail: mwnass@outlook.com; marius.naess@niku.no.
} 


\section{INTRODUCTION}

Cashmere wool has been produced for millennia across remote semi-arid tracts of Central Asia and Mongolia, but especially in western China which produces the world's finest and whitest cashmere (Waldron et al. 2014, 593). ${ }^{2}$ Since the mid-eighteenth century, cashmere from this region has been exported to Europe for processing into cashmere products worn by the aristocracy (Waldron et al. 2014, 593). Cashmere products was considered a luxury item until the 1970s and 1980s when it became more and more popular among the public in the west and Japan

Mongolia and China export 90\% of the world's supply of cashmere wool (Berger et al. 2013) with China as the world's largest producer (Pandit et al. 2014), producing $75 \%$ of the world's cashmere (Waldron et al. 2014, 590). Before the 1990s almost all of China's cashmere was sold to processors in Europe and Japan, but now China process all the cashmere itself and the domestic market for cashmere products matches the international market (Waldron et al. 2014, 590). Between 2002 and 2010 cashmere prices increased by an annual average of $10 \%$ in China and $11 \%$ in Mongolia with Chinese cashmere enjoying a $20 \%$ price premium over Mongolian cashmere due to being of higher quality (Waldron et al. 2014, 599).

Since the 1960s goat populations in both China and Mongolia has seen a dramatic increase, and from the 1990s until 2010 it even surpassed the number of sheep in China (Figure $1 \& 2)$. According to Waldron et al. $(2014,600)$ while the number of goats increased by an annual average rate of $1.8 \%$ between 2000 to 2008 , the number of cashmere goats increased by $6.5 \%$ annual average rate. The growth in cashmere goats occurred between 2000 and 2003 after which time the number of cashmere goats stabilized at 200000000 (Waldron et al. 2014, 600). While the number of cashmere goats has stabilized in China, cashmere production increased by an annual average of $9.6 \%$ between 2008 and $2008^{3}$, an increase that has primarily been caused by breeding: selecting goats with higher yields and switching out breeds that provide low yields of finer cashmere into breeds that have a higher yield of longer but coarser cashmere wool (Waldron et al. 2014, 601).

Cashmere is produced in small volumes by herders in remote and semi-arid areas and provides an important source of livelihood for nomadic pastoralists: cashmere is the major source of cash income for herders in Mongolia (Lkhagvadorj et al. 2013) and for many of the 7 million pastoralists in western China (Waldron et al. 2014, 590). In the western parts of the Tibetan Plateau, the sale of cashmere wool from goats makes up a substantial part of the nomads' income (Næss 2003).

\section{The challenge of market integration}

The increased importance of cashmere wool in the pastoral economy of Tibetan nomads is an example of the increasing integration into a market economy and nomads' dependence on

\footnotetext{
${ }^{2}$ Central Asian regions that grow cashmere include Mongolia, Afghanistan, north-eastern Iran, Kazakhstan, Kyrgyzstan, northern and western Pakistan, Tajikistan, Uzbekistan and Turkmenistan.

${ }^{3}$ Trade declined in 2009 due to the global financial crisis, but now appears to be making a recovery (Waldron et al. 2014).
} 
cash. It has been argued that the integration of nomadic pastoralists into a market economy causes undue stress on their economic livelihood because the traditional technologies of a subsistence-based economy cannot keep up with the demands of a surplus market (Khazanov 1994). Moreover, the commercialization of livestock and livestock products has been viewed as a modern invention and not part of the "traditional" way of life (cf. Marx 2006). In contrast, Marx (2006) has argued that pastoralists do produce, at least to some degree, for markets, and always have, and therefore depend on the city and the state (see also Homewood 2008). Moreover, it can be argued that the market presents a potential for the nomads to create new ways to diversify risk ${ }^{4}$. From this perspective, the increasing importance of cashmere wool can be viewed as giving them new opportunities instead of decreasing their choices. This can be viewed as a safety measure for nomads: during years when cashmere prices are at the highest households can reduce the number of slaughtered of animals. Nevertheless, cashmere wool production is an unpredictable and variable enterprise, since price changes greatly influence the nomads' level of income.

\section{ETHNOGRAPHIC BACKGROUND \\ Methods}

The research reported here is based on three 2-6-week visits to the Aru Basin, in June 2000, September/October 2000, and May/June 2001. Information was gathered primarily through in-depth interviews using translators ${ }^{5}$ with 10 out of 36 households in June 2000, 15 out of 28 households in September/October 2000, and 15 out of 24 households in May-June 2001. Informal interviews were made with all households present in the basin during one of our three trips, and interviews with local leaders and Tibet Autonomous Region (TAR) Forestry Bureau officials was also undertaken (Næss 2003).

\section{The cashmere producers on the Tibetan Platean}

The nomadic pastoralists (or Drokba) on the of the Tibetan Plateau rely mainly on three different species of domesticated animals for subsistence: sheep; goats; and the indigenous yak. The domestication of the yak (Tib.: g.yag) was probably the single most important factor in making it possible for people to adapt to the ecological marginal areas of the Tibetan plateau (Ekvall 1968, Goldstein and Beall 1990, Miller 1998). The yak is unique to the Tibetan Plateau and surrounding areas, and it is very well adapted to the cold and high altitude of the Chang Tang. Tibetans generally call the yak nor, a word that normally translates as "wealth" (Goldstein and Beall 1990). The term yak only refers to the male nor, while $d r i$ ("bri) refers to the female. While body mass of yaks varies according to region and breed (see Wiener et al. 2003, Table 2.1b for details), an adult male yak weigh between $200-250 \mathrm{~kg}$, and

\footnotetext{
${ }^{4}$ Following Cashdan (1990), risk can be seen to have two different aspects. First, risk may be defined as unpredictable variation in ecological or economic variables, and outcomes are viewed as riskier depending on their degree of variability. Second, risk may be related to the probability of loss, i.e. situations when falling below a minimum level of income or food intake is likely.

${ }^{5}$ For an extensive discussion on the use of translators during this study, see Næss (2003:13-14).
} 
is about $1.2 \mathrm{~m}$ tall at the shoulder and $1.3 \mathrm{~m}$ long, while female yaks are around 20-25\% smaller (Goldstein and Beall 1990). Traditionally, yaks were used for transportation, since they are extremely powerful and display great endurance at high altitudes. The yak also provides the nomads with food, shelter and clothing. The yaks' coarse belly hair is spun and woven into tent material. The much finer down fibre is used to make ropes and blankets. Traditionally, the yaks' hide was used to make soles of shoes or boots, but nowadays most nomads prefer to buy shoes, which, although of lower quality, are labour saving. Yaks also provide the nomads with meat, the butchering weight of a full-grown male yak can be as much as $80-125 \mathrm{~kg}$ (Goldstein and Beall 1990). Also, the female yak can provide large quantities of milk throughout the year. Although the yak is usually considered to be the main distinguishing animal in Tibetan nomadic pastoralism, sheep were traditionally more important in the Tibetan nomads' overall economy (Ekvall 1968, Goldstein and Beall 1990).

The sheep and goats that inhabit the Tibetan Plateau are adapted to a life at high altitude. Sheep have more haemoglobin and larger lungs than sheep living at lower altitudes, and have also a thick coat of wool (Goldstein and Beall 1990). Goats also have more haemoglobin, more red cells, and breathe four times faster than goats living at lower altitudes (Goldstein and Beall 1990). Both sheep and goats provide the nomads with milk, meat, wool and skins and while goats produce more milk, and for longer periods of time than sheep, milk and meat from sheep is generally preferred (Næss 2003). Wool has been the most important trade item for the nomads for quite some time. Wool from e.g. Amdo county [Naqu (Nagchu) prefecture, Tibet Autonomous Region (TAR)] has had a commercial reputation for a long time and before 1959, a profitable India wool trade resulted in the development of a wealthy Tibetan trading class who exported wool and imported rice, dye materials, ironware, sugar, tea, cloth, and rifles from India (Liu 2002, 13-14). The proximity to the Indian border, more specifically to the Ladakhi market, made goats an important factor in the economic life of nomads inhabiting the western parts of the Tibetan Plateau. Accordingly, there has been a long tradition of trading cashmere wool between nomads of the western parts of Tibet and traders from Ladakh; and cashmere wool was also to some extent used to pay taxes ${ }^{6}$. That notwithstanding, sheep were traditionally more important for the overall economy for nomads on the western parts of the Tibetan Plateau than goats, because of the preference for sheep milk and meat (Næss 2003).

\section{The Aru Basin}

The Tibetan Plateau reaches around $1500 \mathrm{~km}$ North-South and around $3000 \mathrm{~km}$ East-West and is around 2.5 million $\mathrm{km}^{2}$. Over $80 \%$ of the plateau is located above $3000 \mathrm{~m}$ in elevation, and about $50 \%$ is $>4500 \mathrm{~m}$ (Schaller 1998, Miller 1998). The Tibetan nomadic pastoral area

6 One of the oldest nomads claimed that the Aru basin was under the jurisdiction of the Sera monastery in Lhasa prior to the Chinese occupation in 1959. This area was formally recognized by the authorities since as subjects of the Sera monastery in Lhasa the Aru nomads were obligated to pay a part of their production to the monastery as annual taxes. A household owning 100 heads of livestock could choose to pay in live animals ( 1 yak or 6 sheep or 7 goats), butter and cheese (around $2.5 \mathrm{~kg}$ of cheese or $5 \mathrm{~kg}$ butter), or one bag of goat cashmere wool (see Næss, 2003). 
encompasses a sub-region where the rangelands of the Tibetan Plateau includes all of TAR and Qinghai, most of the rangeland areas of Gansu and Sichuan, and parts of southern Xinjiang; an estimated 1.6 million $\mathrm{km}^{2}$ (Miller 2000). During winter, temperatures around $30^{\circ} \mathrm{C}$ are not uncommon and snowstorms occur even during summer (Schaller 1996), and might have severe negative effects on both livestock (Yeh et al. 2014, Miller 2000, Goldstein and Beall 1990, Nori 2004, Næss 2003, Næss 2013) and wildlife (Schaller and Ren 1988). Annual precipitation varies from $700 \mathrm{~mm}$ in the east to less than $100 \mathrm{~mm}$ in the west, mostly falling as snow and hail during summer (Miller 1998).

An estimated 12 million yaks and 30 million sheep and goats inhabit the Tibetan Plateau supporting around 5 million pastoralists and agropastoralists (Sheehy et al. 2006, 143, Harris 2010,3)7. Additionally, horses are also kept, but then mainly for riding and as pack animals (horses are almost non-existent in the western parts due to predation, Næss 2003). Herd composition varies from west to east on the Tibetan Plateau, with herders keeping predominately yaks in the east and sheep and goats in the west (Næss 2012, 100).

The ca. 300,000 $\mathrm{km}^{2}$ Chang Tang Nature Reserve (Figure 3), the second largest protected area in the world, was established in 1993 (Miller and Schaller 1996) to protect endangered chiru, wild yak and other wildlife inhabiting the Tibetan plateau (Schaller 1998). The Aru Basin is approximately $2300-\mathrm{km}^{2}$ with most of its area lying above $5000 \mathrm{~m}$. The basin is northwest southeast trending, encompassing two lakes, Aru Co (4 $960 \mathrm{~m}$ a.s.1.) and Memar Co or Di-Ngorok Co (4 940 m a.s.1.). The $6000 \mathrm{~m}$ a.s.1. permanently snow-covered mountains along the western edge of the basin create a moist and productive environment compared to other areas on the Chang Tang, and consequently the basin is an attractive place for both wild herbivores and nomadic pastoralists. The Aru Basin is an important wildlife area in the Chang Tang Nature Reserve (Schaller and Gu 1994), and has therefore been designated as a core area for wildlife protection within the reserve (Fox et al. 2004).

\section{Nomads in the Aru Basin}

Although pastoralists and hunters have used the Aru Basin for several thousand years, its use has changed in recent time. At the beginning of the 1900's the Aru Basin was used by a small number of pastoralist/hunter families during winter when hunting was at its most productive; the rest of the year nomads herded their livestock south of the basin (Næss and Bårdsen 2016). During the Cultural Revolution in western Tibet (the effects of which lasted from around 1972 to 1983 in this area according to the nomads) and the years after, the basin was left uninhabited for around 15-20 years. During this period private ownership of animals was banned and nomads were settled in communes close to already existing government centres (Næss 2003, Næss 2013, Næss et al. 2004). From the early 1990's on pastoralists moved back into the basin, and today administrative responsibilities for the basin is divided between two counties, or xians, namely Rutok and Gertse (Figure 3). The basin is currently inhabited

\footnotetext{
${ }^{7}$ It is difficult to assess the correct number since it is unclear how exactly the authors define the term "agropastoralist" (see the discussion in Gruschke 2012:101 for details).
} 
during summer by around 222 nomads with 10,000 sheep and goats, 500 yaks, as wells as 127 nomads with 7,000 sheep and goats, and 330 yaks during fall and winter ${ }^{8}$ (Næss 2003, Næss et al. 2004, see Figure 4 A for livestock distribution). Consequently, the use of the basin changes seasonally, with summer as the season with the highest density of livestock and people.

\section{RESULTS}

\section{Market integration and the increasing importance of cashmere wool}

The implementation of the new economic reform policy in Tibet Autonomous Region (TAR) by the end of the Cultural Revolution brought the nomads in TAR closer to a market economy. Traditionally, trading played an important part in the nomads' way of life since they relied on other products than livestock products to make a living. Until very recently trading was the usual way to obtain goods they don't produce: Goldstein \& Beall $(1990,100)$ report that the Phala nomads traded one sheep for $20-35 \mathrm{~kg}$ of barley as late as 1987 and that they got around two and a half $\mathrm{kg}$ of barley for $0.5 \mathrm{~kg}$ sheep wool.

Today, nomads sell their livestock products, primarily wool, on governmental markets, receiving money used to buy needed products. Consequently, the Aru nomads are now more dependent on cash than before. The Aru nomads reported that they could (in 2001) get around RMB $200^{9}$ for one live sheep, RMB 100 for one goat and around RMB 800 for one yak. Meat from one sheep would give them RMB 100, RMB 50 for the meat from a goat and RMB 800-850 for the meat from a yak. However, the Aru nomads usually do not sell meat since the only places where they can sell meat is at town centres, and the nearest one is a twothree days journey away by car, making it too expensive with regards to time, fuel and maintenance of the car etc., to undertake such a journey. What they do sell is wool, and then especially cashmere wool, which has increased in importance along with the increasing prices for cashmere wool.

Cashmere wool has become more and more popular among the public in the west. With the increasing popularity of cashmere products, the government of PRC, including the TAR, has become increasingly concerned with trying to control cashmere wool production within its borders. Cashmere wool is the soft down undercoat of goats, and the nomads comb the cashmere out with long teethed combs. Then they continue by cutting the long hairs, or tsiba, with knives so that they can get to the rest of the cashmere wool, which is sheared in June because this is when the cashmere wool has the best quality. Some nomads also try to "weed" out most of the long, coarse hairs that tend to be mixed in with the soft cashmere wool, arguing that this will give them a better price on the market.

The Aru nomads must fill quotas of both sheep wool and goat cashmere; the amount is determined by the local government and is based on each household's herd size, and the amount of wool one animal is estimated to produce. However, the governmental quotas are

\footnotetext{
${ }^{8}$ However, the number of people and animals within the basin during winter is extrapolated from the numbers from autumn since no data is currently available for that season.

${ }^{9}$ RMB $100=$ USD 14.97 per 01.09.2016.
} 
usually higher per animal than average yields (Table 1). Failure to provide the quota is punished by a fine of RMB 15 for each animal, both sheep and goats. Fines are usually determined after estimating the households' economic capacity, i.e. its capacity to pay the fine. In general, failure to meet sheep wool requirements is usually not punished since sheep wool is not as important as cashmere wool.

The Aru nomads are entitled to keep around 10-15 kg of sheep wool or goat cashmere wool for their own use or sell to private traders. Because of the high price for cashmere wool, and because sheep wool is of more use to themselves, they tend to sell all their cashmere wool on governmental markets and keep all the sheep wool since it can be used for everything from making clothes to blankets. Cashmere production makes up a substantial part of the Aru nomads cash income. For example, in September/October 2000 an average household (4.5 people, 165 sheep, 82 goats and 12 yaks) in the Aru basin made around RMB 4000 from the sale of cashmere wool and sheep wool in June. While goats, on average only comprised around $30 \%$ of the total herd (Figure 5), the income from cashmere wool comprised around $70 \%$ (Næss 2003).

\section{Changing herd composition}

Traditionally, cashmere wool was not of major importance for the pastoral economy (Ekvall 1968, Goldstein and Beall 1990, Goldstein et al. 1990), although they did barter and could also pay taxes with cashmere wool. Traditionally, they kept more sheep than goats, and probably also valued sheep more than goats (Ekvall 1968). However, with an increasing demand from the government to produce excess cashmere wool, they have begun to value goats more than sheep. Although goats produce more milk than sheep, nomads tend to value milk from sheep more than from goats, illustrated by the fact that they blend goat milk with sheep milk. Also, goat milk is primarily used because they do not have enough sheep to cover their need for milk products. The nomads also prefer to eat meat from sheep. Sheep wool is of more use to the nomads than cashmere wool, because it is used to make bags, clothes and carpets, while they use only the long coarse hairs from the goat to make ropes.

For China in general, sheep number predominated goats until the early 1990s when goat numbers seem to have surpassed that of sheep (Figure $1 \& 2$ ). According to Goldstein \& Beall (1990), with the increasing importance of cashmere wool, goats could be the new economic basis for nomadic pastoralists in Tibet. In 1981 the ratio between sheep and goats in Phala were 3:2, while in 1988 the ratio was 1:1. Even though cashmere prices have increased since the Phala study, and the nomads' preference for sheep meat leading to a higher off take of sheep as opposed to goats (Goldstein and Beall 1990), data from the Aru Basin indicates a relatively low proportion (30\%) of goats (Næss 2003, Næss et al. 2004, see Figure 5) compared to that of Phala. One of the reasons for this, according to some of the nomads, is that the mortality rate for new-born goats is much higher than for sheep. Some claimed that this was because the grass in the basin is much better for sheep than for goats, resulting in 
goats not producing enough milk for their kids after giving birth, but it is difficult to assess such information.

While traditionally the Aru nomads preferred sheep to goats, this is about to change. This change can be related to a change from a 'traditional' subsistence and surplus for trade economy to a 'modern' subsistence and surplus for cash economy. The Tibetan nomads have always produced surplus products traded to obtain necessary products such as tea, barley and rice. However, the traditional surplus products traded were mainly that from sheep and, to some extent yak. Today, the most valuable product sold for cash is goat cashmere wool. As such, the production system can be viewed as changing from a mainly sheep-oriented economy to that of goat. This is reflected in the nomads' preferences, while they still value sheep products for own use more than goat products, they now place more value on goats, for as they say cash can be used to buy anything. Following PAINE $(1994,15)$ terms of 'intrinsic value' and 'market value', sheep can be viewed as more valued than goats within the domain of "subsistence" economy i.e. the intrinsic value is higher, while goats are more valued in the domain of the market economy and its culture.

Although, this change in preference has yet to manifest itself clearly in herd composition of the Aru nomads herds ( $7: 3$ sheep goat ratio) as that of Phala (1:1 sheep goat ratio,Goldstein and Beall 1990), it is probable that this will change in the near future if cashmere wool prices continue to be high since almost $70 \%$ of the Aru nomads cash income derives from the sale of cashmere wool (Næss 2003, Næss et al. 2004).

\section{Changing sex composition}

Cashmere prices also reflect quality of the product, with white, for example, giving a better price than coloured cashmere. Also, male adult goats tend to yield more $(0.15 \mathrm{~kg}$ on average $)$ and better-quality cashmere wool than female goats $(0.1 \mathrm{~kg}$ on average). According to the nomads this is because pregnant goats diverts energy to the foetus, which reduces the growth and quality of the wool. Also, pregnant goats tend to demand more care from the nomads and increased physical contact between nomads and animals leads to shedding of some wool. Consequently, wool from female goats gives a much lower price on the governmental market than wool from male goats. The quality is also dependent on the amount of fodder that the animals get. During years with heavy snowfall and scarce access to fodder, the cashmere will be of poorer quality, again giving a lower price. Consequently, there are now more male goats in a herd of goats in Aru than necessary for just reproductive purposes (see Figure 4 B).

The average proportions of female animals relative to total number of adult animals in goat herds from Rutok xian in the Aru basin was approximately 0.5 while for Gertse xian it was approximately 0.57 (see table 2 for more details). A similar pattern was also observed for sheep: the average proportions of female animals relative to total number of adult animals from Rutok xian in the Aru basin was approximately 0.45 while for Gertse xian it was approximately 0.52 (see Table 2 for details). To put the numbers in context, Miller (2000) states that in the Phala region, almost $60 \%$ of adult sheep and goats are females. Miller (2000) argues that the relatively large proportions of male animals are not related to the 
reproductive ability of the herd, since only 2-3 male animals are kept fertile, the rest are castrated. Miller (2000) indicates this proportion is explained by the fact that a relatively large proportion of the nomads' income derives from sheep wool and cashmere wool. The proportion of female animals in the Aru basin is lower than what Miller (2000) notes for the Phala area, and the raison d'etre for keeping herds with a higher ratio of male/female animals is therefore connected with the increased importance of wool sale. Also, as in Phala, there is a preference for sheep meat in the Aru basin, and male sheep yield more meat because of their size. Size differences also have consequences for sheep wool production; male sheep yield on average $0.75 \mathrm{~kg}$ of wool, while female sheep only yield 0.5 . Nevertheless, since sheep wool is not as valuable as cash crop as cashmere wool, the high ratio of male sheep is probably not connected to the sale of wool. As previously stated, sheep wool is of more use to the nomads themselves, and maybe the high ratio of male sheep can be explained by the demand for sheep wool for their own use as well as meat. Furthermore, sheep give birth January, when winter is at its hardest. This can exert a large amount of stress on female animals: grass is scarce and since a lot of energy goes to the caring of the new-born, which could result in a higher mortality rate for female sheep than for male sheep during the precarious winter months.

\section{DISCUSSION}

The increasing importance of cashmere wool can be viewed as giving the Aru nomads new opportunities instead of decreasing their choices. However, this change in economic patterns can have long-term consequences that can be problematic for the pastoral system to deal with.

\section{The vicissitudes of cashmere production}

In general, it can be argued that the way pastoralists organize the keeping of multiple species herds reflects risk diversification ${ }^{10}$. Keeping multiple species can have some advantages: herds tend to be more stable and permit a wider use of pasture. Also, if one species experiences great losses, another of the available species can, to some extent compensate for this loss, because the different species' capacity to cope with different natural disasters, and reproductive ability, varies between different species (Khazanov 1994). The keeping of multiple species also reflects a subsistence diversification strategy, i.e. different eggs in different baskets (Cashdan 1990, Næss 2003). As seen, the Aru nomads keep goats mainly for surplus purposes, while sheep are mainly kept for subsistence purposes. The raison d'etre for

\footnotetext{
${ }^{10}$ Halstead \& O'Shea (1989) argues that societies, in general, employ a wide range of strategies or 'buffering mechanism' to counteract scarcities, including everything from myths to alternative modes of subsistence (see also Bollig and Göbel 1997). Following Halstead \& O'Shea (1989), strategies for countering risk can be grouped into four major categories; (a) diversification, ranging from the keeping of multiple livestock species (e.g. Khazanov 1994, White 1997) to investing in non-pastoral activities (e.g. Bayer and Waters-Bayer 1990, Berzborn 2007, Lesorogol 2008, Mearns 2004, Sperling 1987, Thornton et al. 2007, Næss and Bårdsen 2016), (b) exchange, livestock exchange networks such as stock-friendship (e.g. Bollig 2006:287, Göbel 1997, White 1997), (c) mobility, e.g. taking advantage of spatial and temporal heterogeneity in available forage (e.g. Bollig and Göbel 1997, McCabe 1997, Hobbs et al. 2008, Behnke et al. 1993, Næss 2013) and (d) storage, e.g. large herd size (Bollig and Göbel 1997, Hjort 1981, Ingold 1986 \{Næss, 2010 \#1604, Næss and Bårdsen 2013).
} 
keeping of sheep can be explained as a subsistence strategy (wool and meat), while the keeping of goats can be explained as a surplus strategy (cashmere wool).

Nevertheless, cashmere production entails a production risk in itself: cashmere prices tend to fluctuate, depending on international and national markets' demand, causing the nomads' economy to fluctuate on a year-to-year basis. The price for cashmere wool has seen an overall increase during the last years, and while from 1986 to 2005 the price for cashmere wool increased by $669 \%$ (see Goldstein 2012, Table 14.4 for more information). ${ }^{11}$

Nevertheless, seasonal and annual fluctuations can be dramatic. The Aru nomads reported that during the years 1990-1999 prices ranged from RMB 65 per jin in 1999 to RMB 170 per jin in 1998 (Figure 6). On the southern plateau, in 1988 the county trade office in the Phala area, Shigatse Prefecture, paid nomads RMB 13 per jin ${ }^{12}$ of cashmere wool (Goldstein and Beall 1991), whereas in 2000 nomads from the Aru basin were paid RMB 150 per jin. Over the same period, sheep wool prices have not increased, with the Phala nomads receiving RMB 3 per jin in 1987 (Goldstein and Beall 1991), and the Aru nomads receiving RMB 2.1 per jin in 2000 .

Also, the nomads must sell most of their cashmere production to the government, even though they would get better prices from private traders. For example, in 1999 the government paid RMB 65 per jin, while the price from the private traders was almost RMB 20 higher. This was also the case between 1993 and 1999, while in 2000 the government price and the price from private traders were equal. These factors influence the nomads' level of cash income, and therefore, the sale of cashmere wool is an uncertain and risky enterprise and a family's income will dramatically oscillate depending on the fluctuation in cashmere prices, while an individual family's expenses with regards to taxes, food, clothes are rather permanent from one year to the next. In Mongolia, it has been observed that herders deal with the unpredictability of cashmere prices by increasing herd size: market price for cashmere was stable until 2008, but in the spring of 2008, it fell by half thus reducing the value per head of goat. Consequently, herders had to increase herd sized to maintain income levels (Batkhisig et al. 2012).

\section{Increasing goat populations and overgrazing?}

In China, and elsewhere, there has been a growing concern with rangeland degradation. According to Harris (2010), in 1999 the State Environmental Protection Agency estimated that one-third of China's grassland were degraded, but in a very short time the figure that is often cited increased to $90 \%{ }^{13}$. It is often assumed that pastoralists are trapped in social dilemmas where individuals act independently and seek to maximise short-term gain at the detriment of collective benefits (Mwangi 2007). Hardin (1968) — with the introduction of the

\footnotetext{
11 During the same period Goldstein (2012, Table 14.4) reports that the price for sheep wool increased by $132 \%$.

121 jin is around $0.5 \mathrm{~kg}$, and 1 male goat of average size yields approximately 0.3 jin cashmere. A female yields a little less.

${ }^{13}$ Generally, estimation of degradation in China has been based on varying subjective measures and poorly documented - no systematic investigations has been undertaken (Reid et al. 2014).
} 
'Tragedy of the Commons' (ToC)—provided a framework predicting that pastoralists would increase stocking rates to such a degree that overgrazing was inevitable, in other words pastoralists are 'overstockers'. This implies that pastoralists are unable to establish rules and norms that minimise e.g. overgrazing (Mwangi 2007). Consequently, nomadic pastoralists have been viewed as non-rational, and professionals and governments have viewed problems, such as pasture degradation, as inherent in the nomadic pastoral adaptation (e.g. Lamprey 1983). While official livestock statistics should be interpreted with care (Harris 2010), China in general seem to have experienced an increase in both sheep and goat populations (Figure 1). Cincotta et al. (1992) documented a general increase in both summer and winter herds since decollectivization in northern Qinghai. As prices for livestock products has increased and markets have become more accessible, larger herds meant larger profits for herders (Harris 2010).

The growth in goat populations is especially disconcerting since goats are likely to cause significantly more damage than sheep (Hilker et al. 2014). Goats have been defined as 'the black sheep' among livestock by consuming almost everything edible (Rosa García et al. 2012) and are most responsible for rangeland deterioration because they destroy grass at its root while grazing (Endicott 2012, 4) ${ }^{14}$. Waldron et al. $(2014,600)$ for example, argues that overstocking, and then especially of goats has "[...] led to the degradation of virtually all of the grasslands in western China".

The increasing dominance of goats is also observed in Mongolia: while the ideal herd composition has been said to be 3:1 in favour of sheep (because goats have the habit of grazing grass down to the roots), in 2000 this had changed to 1.2:1 and in 2008 goats outnumbered sheep (Endicott 2012, Sekiyama et al. 2014). In Jints Soum Mongolia, before the collapse of the collective in 1989, sheep and goats accounted for 40-60\% of total livestock but by 2008 it had changed to $15 \%$ sheep and $82 \%$ goats (Batkhisig et al. 2012, 120). In short, herders began to raise more goats because cashmere became the main source of income and goats are now considered more valuable than sheep because cashmere is easier to harvest, store and market and also has lower transaction and handling costs. In western Mongolia, Lkhagvadorj et al. (2013) found, for example, that the number of goats could explain $51 \%$ of the variation in family income due to sale of cashmere which contributed $60 \%$ of the total cash income from livestock keeping. ${ }^{15}$ Mongolia has, as China, seen significant decline in grasslands and over 70\% of the steppe is considered degraded (Hilker et al. 2014) and a marked increase in goat density and wild fires are the most likely non-climatic factors behind the degradation (Liu et al. 2013).

\footnotetext{
${ }^{14}$ Most of the environmentally harmful effects of goat grazing are linked to improper management practices (Rosa García et al. 2012)

${ }^{15}$ The mean yearly production of cashmere was $23 \mathrm{~kg}$ per household, which was sold at prices $40-57$ USD per $\mathrm{kg}$.
} 


\section{Sex composition and long-term household viability}

Pastoralists live in marginal areas and are experienced at coping with climatic variability (Galvin 2009). Scenarios for future climate change generally predict an increased average, variance and even a changed distribution of important climatic variables like precipitation and temperature (e.g. Rowell 2005, Sun et al. 2007), a trend that is evident for the Tibetan Plateau (Chen et al. 2013). Moreover, these changes are predicted to vary both temporally (e.g. Rowell 2005) and spatially (e.g. Hanssen-Bauer et al. 2005). Climate change is expected to result in increased frequencies of extreme weather events (e.g. Sun et al. 2007, Tebaldi et al. 2006), a trend that is already empirically evident on several continents (e.g. Sun et al. 2007). The Tibetan Plateau is no exception as both increased annual temperatures (as much as 2.6$5.9^{\circ} \mathrm{C}$ by 2100 where the most drastic changes occur in the autumn and winter) and annual precipitation (38-272 $\mathrm{mm}$ ) is predicted to happen (cf. Chen et al. 2013). As for pastoralists in general, GALVIN (2009) argues that severe events are occurring with increased frequency and longer duration on the worlds' dry grasslands. For Asia specifically, long series of droughts and winter disasters of 1999-2002 in Mongolia have been argued to be unprecedented (Marin 2010). Importantly, droughts have almost doubled in frequency during the last 60 years and the worst droughts on record ( $>50-70 \%$ of the country) have occurred during the last decade (Marin 2010, 171). In 2007, western parts of the Tibetan Plateau experienced nine continuous days of gale force wind and dust storms, a 20-year record high. In June the same year, western areas reported an average temperature increase of $1-2^{\circ} \mathrm{C}$ and an average decrease in precipitation by $20-90 \%$ (Anonymous 2009,15 ). In general, during the past few decades evidence indicates increased spring snow accumulation as well increased frequencies of large snowstorms on the Tibetan Plateau (cf. Yeh et al. 2014).

There is a growing body of evidence showing the detrimental effects of environmental hazards like snowstorms and drought on nomadic pastoralists (cf. Næss and Bårdsen 2016). Tibetan nomads have always had to deal with snowstorms and cold weather, making nomadic pastoralism on the Tibetan Plateau a high-risk enterprise (Goldstein and Beall 1990, Miller 2000) where decisions have always been aimed at mitigating risks and averting disasters (Sheehy et al. 2006). While environmental induced risks are problematic for pastoralists in general, according to Sheehy et al. (2006), these risks are an especially critical constraint for nomadic pastoralists in Tibet: the winter of 1997-1998, for example, resulted in a loss of up to $70 \%$ of the total livestock population for some townships in TAR. By April 1998 it was estimated that the region had lost over 3 million head of livestock, estimated as a loss of US \$ 125000000 (Miller, 2000 \#146, see Næss and Bårdsen 2016 for more examples). Snow, and especially blizzards, affects the Aru nomads as well. During the winter of 1997-1998 one household lost $50 \%$ of around 1200 sheep and goats while another lost $~ 50 \%$ of its herd of 1 000 during one night in 1997. Another group in the basin reported that they lost around 500 animals during the same winter. In the spring of 2001, one group of nomads ( $n=11$ households) reported an average of 34.93\% mortality (range 5.04-63.29\%), against an average recruitment of new-borns of $21.33 \%$ (range $8.83-56.12 \%$, Figure $4 \mathrm{C}$ ) based on herd size from previous year (Næss 2003). The high losses were primarily attributed to severe snowfall 
conditions especially during April and May (many carcasses of sheep and goats were observed near some of the late winter encampments, Næss 2003).

As argued above, an important strategy for managing risk is species diversification and it has been argued that "[...] pastoralists attempt to maintain a herd whose size and age/sex structure will enable them to withstand the vicissitudes of risky conditions" (White 1997, 94). The Aru nomads do try to influence the composition of their herds, both with regard to species-, age- and sex-composition. They have to make husbandry decisions in order to balance subsistence needs of a household and surplus need for wool for sale on governmental markets. For sexual composition, they have to find a balance between raising male goats, from which they can sell cashmere wool, and the need to raise female goats that are both necessary for the continued reproduction of the herd and which would give a much needed milk, i.e. they have to consider both the growth of capital as herd and the growth in cash profit as the yield of cashmere wool from individual animals. For the nomadic populations in Aru an adequate number of reproducing females to provide offspring are necessary, both to replace older and slaughtered animals in the herd, but also to provide males that give more and higher quality wool.

For the Masaai in Kenya it has been reported that male goats make up 9\%, castrates $23.6 \%$ and females $67.4 \%$ of goat herds (King et al. 1984, 42) while in western Sudan it has been reported that males and females make up $23.6 \%$ and $76.4 \%$ respectively of goat herds (Dahl and Hjort 1976, 96). The focus on cashmere selling cashmere wool might thus have changed the traditional sex composition of goat herds (and sheep herds, but for different reasons, see above) from a larger proportion of females than males to a more balanced 1:1 ratio of male/female. A decrease in number of female animals in a herd will most likely have consequences for the growth potential of the herds. Consequently, herds with large proportions of adult male animals will be more affected by climatic perturbations, and the recuperation potential for herds will be decreased. This is especially relevant when considering climate change: a delay in recuperation after environmental-induced losses has been argued to be one of the main problems of pastoral production (Bollig and Göbel 1997, 8). While cashmere wool provide the nomads with a source of cash in the short term, a reduced reproductive potential due to a smaller female segment coupled with increased frequencies of severe events due to climate change might reduce long-term household viability.

\section{CONCLUDING REMARKS}

While some researchers have criticized the integration of nomadic pastoralists into a market economy causing undue stress on their economic livelihood because the traditional technologies of a subsistence-based economy cannot keep up with the demands of a surplus market (Khazanov 1994), it can be argued that the market present a potential for the Aru nomads to create new ways to diversify risk. From this perspective, the increasing importance of cashmere wool can be viewed as giving them new opportunities instead of decreasing their choices. This can be viewed as a safety measure for nomads: during years when cashmere 
prices are high, households can decrease the slaughter of animals. Nevertheless, cashmere wool production is an unpredictable and variable enterprise, since price changes greatly influence the nomads' level of income.

Nevertheless, the increasing importance of cashmere and the increasing value of goats might result in long-term negative consequences: it has for example been argued that rangeland degradation in both western China (Waldron et al. 2014) and Mongolia (Liu et al. 2013) has been caused by overstocking of goats because they destroy grass at its root while grazing (Endicott 2012, 4).

Furthermore, a proportional decrease in number of females relative to males will most likely have consequences for the growth potential of herds. Consequently, herds with large proportions of adult males will be more affected by climatic perturbations, and the recuperation potential for herds will be decreased.

\section{ACKNOWLEDGMENT}

The funding for writing this paper was provided by the Research Council of Norway [grant number 240280]. Support for this research was provided through personnel assignments and other inputs by the Tibet Autonomous Region Forestry Bureau, and the Tibet Academy of Social Sciences (TASS), with primary funding supplied through the Network for University Cooperation Tibet - Norway. I thank Joseph L. Fox for his role as a project leader for the project Biodiversity conservation and the maintenance of pastoralism in western Tibet. I would also like to thank Per Mathiesen for his role as supervisor on the thesis that formed the basis for this paper. I also give thanks to Chris Ladue for help with the Wylie transliterations, and extend great appreciation to all the nomads of the Aru Basin for their cooperation in the project. Finally, I would like to thank the late Andreas Gruschke whose comments helped improve this paper.

\section{REFERENCES}

Anonymous. (2009). The Impacts of Climate Change on the Tibetan Plateau: A Synthesis of Recent Science and Tibetan Research. Environment and Development Desk Department of Information and International Relations (DIIR) Central Tibetan Administration, Dharamshala, India, pp. 64.

Batkhisig, B., Oyuntulkhuur, B., Altanzul, T., and Fernández-Giménez, M. E. (2012). A case study of community-based rangeland management in Jinst Soum, Mongolia. In M. E. Fernández-Giménez (eds.), Restoring community connections to the land: building resilience through community-based rangeland management in China and Mongolia, CABI, Wallingford, Oxfordshire, pp. 113-135.

Bayer, W., and Waters-Bayer, A. (1990). Relations between Cropping and Livestock-Keeping in Traditional Land-Use Systems in Tropical Africa. Tropenlandwirt 91:133-145.

Behnke, R., Scoones, I., and Kerven, C. Editors. (1993). Range Ecology at Disequilibrium. New Models of Natural Variability and Pastoral Adaptation in African Savannas. London: Overseas Development Institute.

Berger, J., Buuveibaatar, B., and Mishra, C. (2013). Globalization of the Cashmere Market and the Decline of Large Mammals in Central Asia. Conservation Biology 27(4):679689. 
Berzborn, S. (2007). The household economy of pastoralists and wage-labourers in the Richtersveld, South Africa. Journal of Arid Environments 70(4):672-685.

Bollig, M. (2006). Risk management in a hazardous environment: a comparative study of two pastoral societies. Studies in human ecology and adaption, Springer, New York.

Bollig, M., and Göbel, B. (1997). Risk, Uncertainty and Pastoralism: An Introduction. Nomadic Peoples 1(1):5-21.

Cashdan, E. (1990). Introduction. In E. Cashdan (eds.), Risk and Uncertainty in Tribal and Peasant Economies, Westview Press, Boulder, pp. 1-16.

Chen, H., Zhu, Q., Peng, C., Wu, N., Wang, Y., Fang, X., Gao, Y., Zhu, D., Yang, G., Tian, J., Kang, X., Piao, S., Ouyang, H., Xiang, W., Luo, Z., Jiang, H., Song, X., Zhang, Y., Yu, G., Zhao, X., Gong, P., Yao, T., and Wu, J. (2013). The impacts of climate change and human activities on biogeochemical cycles on the Qinghai-Tibetan Plateau. Global Change Biology 19(10):2940-2955.

Cincotta, R., Yanqing, Z., and Xingmin , Z. (1992). Transhumant Alpine Pastoralism in Northeastern Qinghai Province: An Evaluation of Livestock Population Response During China's Agrarian Economic Reform. Nomadic Peoples (30):3-25.

Dahl, G., and Hjort, A. (1976). Having herds: pastoral herd growth and household economy. Stockholm studies in social anthropology, Dept. of Social Anthropology, University of Stockholm, Stockholm.

Ekvall, R. B. (1968). Fields on the hoof: nexus of Tibetan nomadic pastoralism. Case studies in cultural anthropology, Holt Rinehart and Winston, New York.

Endicott, E. (2012). A History of Land Use in Mongolia: The Thirteenth Century to the Present, New York, US: Palgrave Macmillan.

Fox, J. L., Mathiesen, P., Yangzom, D., Næss, M. W., and Binrong, X. (2004). Modern wildlife conservation initiatives and the pastoralist/hunter nomads of northwestern Tibet. Rangifer Special Issue 15:17-27.

Galvin, K. A. (2009). Transitions: Pastoralists Living with Change. Annual Review of Anthropology 38(1):185-198.

Goldstein, M. (2012). Change and Continuity in a Nomadic Pastoralism Community in the Tibet Autonomous Region, 1959-2009. In H. Kreutzmann (eds.), Pastoral practices in High Asia, Agency of 'development' effected by modernisation, resettlement and transformation, Advances in Asian Human-Environmental Research, Springer Netherlands, pp. 257-272.

Goldstein, M., and Beall, C. (1990). Nomads of western Tibet: the survival of a way of life, Serindia Publications, London.

- (1991). Change and Continuity in Nomadic Pastoralism on the Western Tibetan Plateau. Nomadic Peoples 28:105-122.

Goldstein, M., Beall, C., and Cincotta, R. (1990). Traditional Nomadic Pastoralism and Ecological Conservation on Tibet's Northern Plateau. National Geographic Research 6(2):139-156.

Gruschke, A. (2012). Tibetan Pastoralists in Transition. Political Change and State Interventions in Nomad Societies. In H. Kreutzmann (eds.), Pastoral practices in High Asia, Agency of 'development' effected by modernisation, resettlement and transformation, Advances in Asian Human-Environmental Research, Springer Netherlands, pp. 273-289.

Göbel, B. (1997). You Have To Exploit Luck': Pastoral household Economy and the Cultural Handling of Risk and Uncertainty in the Andean Highlands. Nomadic Peoples $1(1): 37-53$. 
Halstead, P., and O'Shea, J. (1989). Introduction: cultural responses to risk and uncertainty. In P. Halstead and J. O'Shea (eds.), Bad year economics: cultural responses to risk and uncertainty, Cambridge University Press, Cambridge, pp. 1-8.

Hanssen-Bauer, I., Achberger, C., Benestad, R., Chen, D., and Forland, E. J. (2005). Statistical downscaling of climate scenarios over Scandinavia. Climate Research 29(3):255-268.

Hardin, G. J. (1968). The Tragedy of the Commons. Science 162:1243-1248.

Harris, R. B. (2010). Rangeland degradation on the Qinghai-Tibetan plateau: A review of the evidence of its magnitude and causes. Journal of Arid Environments 74(1):1-12.

Hilker, T., Natsagdorj, E., Waring, R. H., Lyapustin, A., and Wang, Y. (2014). Satellite observed widespread decline in Mongolian grasslands largely due to overgrazing. Global Change Biology 20(2):418-428.

Hjort, A. (1981). Herds, Trade and Grain: Pastoralism in a Regional Perspective. In J. G. Galaty, D. Aronson, P. C. Salzman, and A. Choiunard (eds.), The Future of pastoral peoples: proceedings of a conference held in Nairobi, Kenya, 4-8 August 1980, International Development Research Centre, Ottawa, pp. 97-103.

Hobbs, N. T., Reid, R. S., Galvin, K. A., and Ellis, J. E. (2008). Fragmentation of Arid and Semi-Arid Ecosystems: Implications for people and Animals. In K. A. Galvin, R. S. Reid, R. Behnke, and N. T. Hobbs (eds.), Fragmentation in semi-arid and arid landscapes: consequences for human and natural systems, Springer, Dordrecht, pp. 2544.

Homewood, K. (2008). Ecology of African pastoralist societies, James Currey; Ohio University Press, Oxford; Athens, Ohio.

Ingold, T. (1986). The appropriation of nature: essays on human ecology and social relations. Themes in social anthropology, Manchester University Press, Manchester.

Khazanov, A. M. (1994). Nomads and the outside world, 2nd edition, University of Wisconsin Press, Madison.

King, J. M., Sayers, A. R., Peacock, C. P., and Kontrohr, E. (1984). Maasai herd and flock structures in relation to livestock wealth, climate and development. Agricultural Systems 13(1):21-56.

Lamprey, H. (1983). Pastoralism Yesterday and Today: the Overgrazing Problem. In F. Bourliers (eds.), Ecosystems of the World 13: Tropical Savannas, Elsevier Scientific Publishing Co, Amsterdam.

Lesorogol, C. K. (2008). Land privatization and pastoralist well-being in Kenya. Development and Change 39(2):309-331.

Liu, Y. (2002). A New Strategy and the Old Land: The Impact of China's Regional Development Policies on a Drokba Community in Tibet. In L. Gelek (eds.), Nomads of Tibet: anthropological fieldwork reports from China, M. E. Sharpe, Armonk, Manuscripts, http://www.case.edu/affil/tibet/tibetanNomads/books.htm.

Liu, Y. Y., Evans, J. P., McCabe, M. F., de Jeu, R. A. M., van Dijk, A. I. J. M., Dolman, A. J., and Saizen, I. (2013). Changing Climate and Overgrazing Are Decimating Mongolian Steppes. PLoS ONE 8(2):e57599.

Lkhagvadorj, D., Hauck, M., Dulamsuren, C., and Tsogtbaatar, J. (2013). Twenty Years After Decollectivization: Mobile Livestock Husbandry and Its Ecological Impact in the Mongolian Forest-Steppe. Human Ecology 41(5):725-735.

Marin, A. (2010). Riders under storms: Contributions of nomadic herders' observations to analysing climate change in Mongolia. Global Environmental Change-Human and Policy Dimensions 20(1):162-176. 
Marx, E. (2006). The Political Economy of Middle Eastern and North African Pastoral Nomads. In D. Chatty (eds.), Nomadic societies in the Middle East and North Africa entering the 21 st century, Brill, Leiden, pp. 78-97.

McCabe, J. T. (1997). Risk and Uncertainty Among the Maasai of the Ngorongoro Conservation Area in Tanzania: A Case Study in Economic Change. Nomadic Peoples 1(1):54-65.

Mearns, R. (2004). Sustaining livelihoods on Mongolia's pastoral commons: Insights from a participatory poverty assessment. Development and Change 35(1):107-139.

Miller, D. (1998). Nomads of the Tibetan Plateau Rangelands in Western China Part One: Introduction and Pastoral History. Rangelands 20(6):24-29.

- (2000). Tough times for Tibetan nomads in Western China: Snowstorms, settling down, fences, and the demise of traditional nomadic pastoralism. Nomadic Peoples 4(1):83109.

Miller, D., and Schaller, G. B. (1996). Rangelands of the Chang Tang Wildlife Reserve in Tibet. Rangelands 18(3):91-96.

Mwangi, E. (2007). Subdividing the Commons: Distributional Conflict in the Transition from Collective to Individual Property Rights in Kenya's Maasailand. World Development 35(5):815-834.

Nori, M. (2004). Pastoral livelihoods on the Qinghai-Tibetan plateau - The case of Chengduo county, Yushu prefecture. ASIA

Næss, M. W. (2003). Living with risk and uncertainty: the case of the nomadic pastoralists in the Aru basin, Tibet. Cand. Polit., University of Tromsø.

- (2012). Tibetan Nomads Facing an Uncertain Future: Impacts of Climate Change on the Qinghai-Tibetan Plateau. In A. Lamadrid and I. Kelman (eds.), Climate Change Modeling for Local Adaptation in the Hindu Kush-Himalayan Region, Community, Environment and Disaster Risk Management, Emerald Group Publishing Limited, pp. 99-122.

-. (2013). Climate Change, Risk Management and the End of Nomadic Pastoralism. International Journal of Sustainable Development and World Ecology 20(2):123-133.

Næss, M. W., and Bårdsen, B.-J. (2013). Why Herd Size Matters - Mitigating the Effects of Livestock Crashes. Plos One 8(8): e70161.

- (2016). Why do Tibetan pastoralists hunt? Land Use Policy 54:116-128.

Næss, M. W., Lhagyal, D., Yangzom, D., Mathiesen, P., Fox, J. L., and Bårdsen, B.-J. (2004). Nomadic pastoralism in the Aru Basin of Tibet's Chang Tang. Rangifer Special Issue 15:39-46.

Paine, R. (1994). Herds of the Tundra: a portrait of Saami reindeer pastoralism. Smithsonian series in ethnographic inquiry, Smithsonian Institution Press, Washington London.

Pandit, M. K., Manish, K., and Koh, L. P. (2014). Dancing on the Roof of the World: Ecological Transformation of the Himalayan Landscape. BioScience 64(11):980-992.

Reid, R. S., Fernández-Giménez, M. E., and Galvin, K. A. (2014). Dynamics and Resilience of Rangelands and Pastoral Peoples Around the Globe. Annual Review of Environment and Resources 39(1):217-242.

Rosa García, R., Celaya, R., García, U., and Osoro, K. (2012). Goat grazing, its interactions with other herbivores and biodiversity conservation issues. Small Ruminant Research 107(2-3):49-64.

Rowell, D. P. (2005). A scenario of European climate change for the late twenty-first century: seasonal means and interannual variability. Climate Dynamics 25(7-8):837-849.

Schaller, G. B. (1996). Realm of the snow antelope. Natural History 105:48-53.

- (1998). Wildlife of the Tibetan steppe, University of Chicago Press, Chicago, USA. 
Schaller, G. B., and Gu, B. (1994). Ungulates in Northwest Tibet. National Geographic Research \& Exploration 10(3):266-293.

Schaller, G. B., and Junrang, R. (1988). Effects of a snowstorm on Tibetan antelope. Journal of Mammalogy 69(3):631-634.

Sekiyama, A., Takeuchi, W., and Shimada, S. (2014). Detection of Grassland Degradation Using MODIS Data in Mongolia. Journal of Arid Land Studies 24(1):175-178.

Sheehy, D. P., Miller, D., and Johnson, D. A. (2006). Transformation of traditional pastoral livestock systems on the Tibetan steppe. Sécheresse 17(1-2):142-151.

Sperling, L. (1987). Wage employment among Samburu pastoralists of Northcentral Kenya. Human Ecology 9:167-190.

Sun, Y., Solomon, S., Dai, A., and Portmann, R. W. (2007). How often will it rain? Journal of Climate 20(19):4801-4818.

Tebaldi, C., Hayhoe, K., Arblaster, J. M., and Meehl, G. A. (2006). Going to the extremes. Climatic Change 79(3-4):185-211.

Thornton, P. K., Boone, R. B., Galvin, K. A., BurnSilver, S. B., Waithaka, M. M., Kuyiah, J., Karanja, S., Gonzalez-Estrada, E., and Herrero, M. (2007). Coping strategies in livestock-dependent households in east and southern Africa: A synthesis of four case studies. Human Ecology 35(4):461-476.

Waldron, S., Brown, C., and Komarek, A. M. (2014). The Chinese Cashmere Industry: A Global Value Chain Analysis. Development Policy Review 32(5):589-610.

White, C. (1997). The Effect of Poverty on Risk Reduction Strategies of Fulani Nomads in Niger. Nomadic Peoples 1(1):90-107.

Wiener, G., Han, J., and Long, R. (2003). The Yak. Second Edition. FAO Regional Office for Asia and the Pacific, Bangkok, Thailand, pp. 460.

Yeh, E. T., Nyima, Y., Hopping, K. A., and Klein, J. A. (2014). Tibetan Pastoralists'

Vulnerability to Climate Change: A Political Ecology Analysis of Snowstorm Coping Capacity. Human Ecology 42(1):61-74. 


\section{FIGURES}
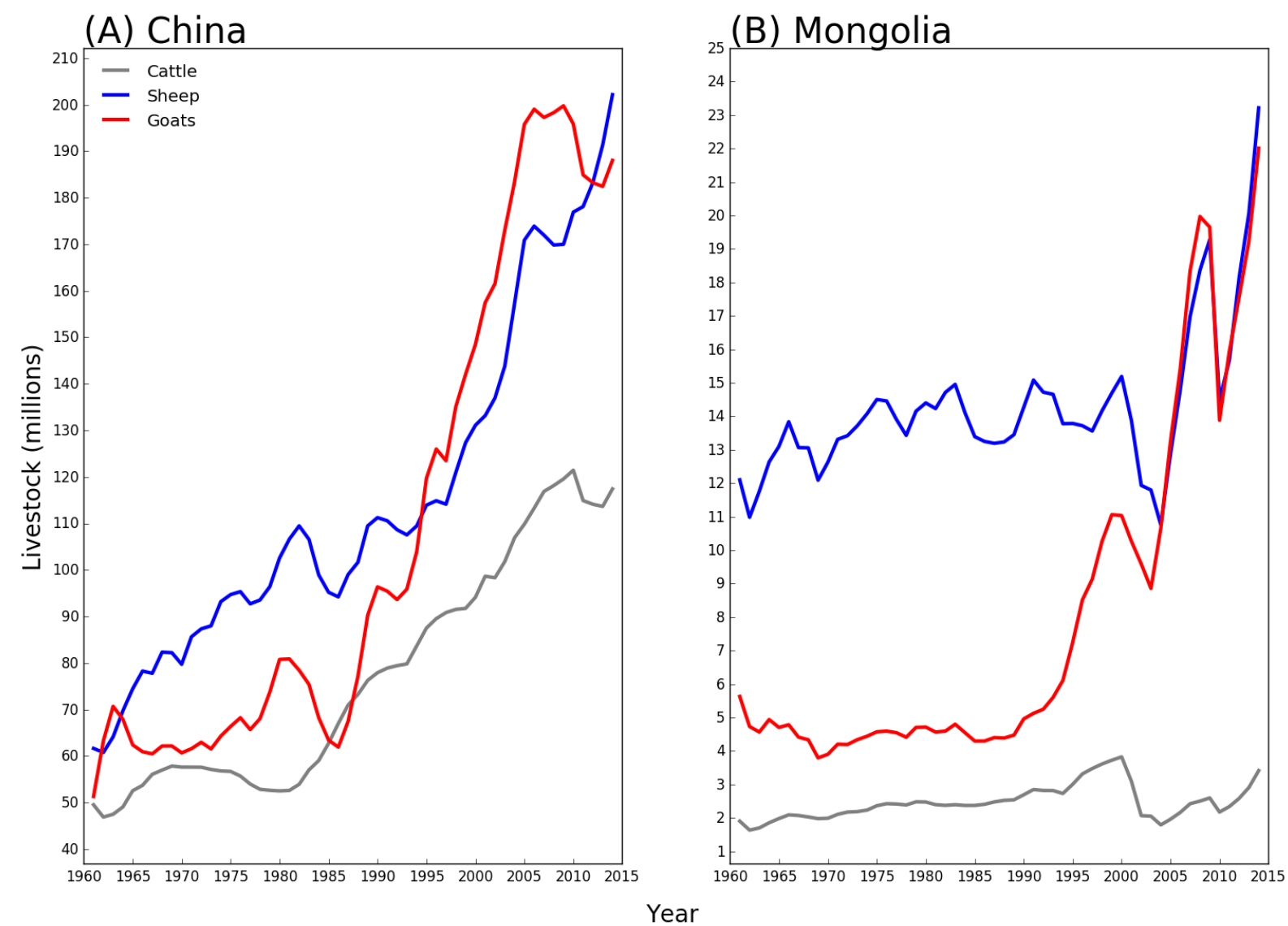

Figure 1. Temporal trends in cattle, goat and sheep populations for (A) China and (B) Mongolia. Source: FAOSTAT (http://faostat.fao.org/). 


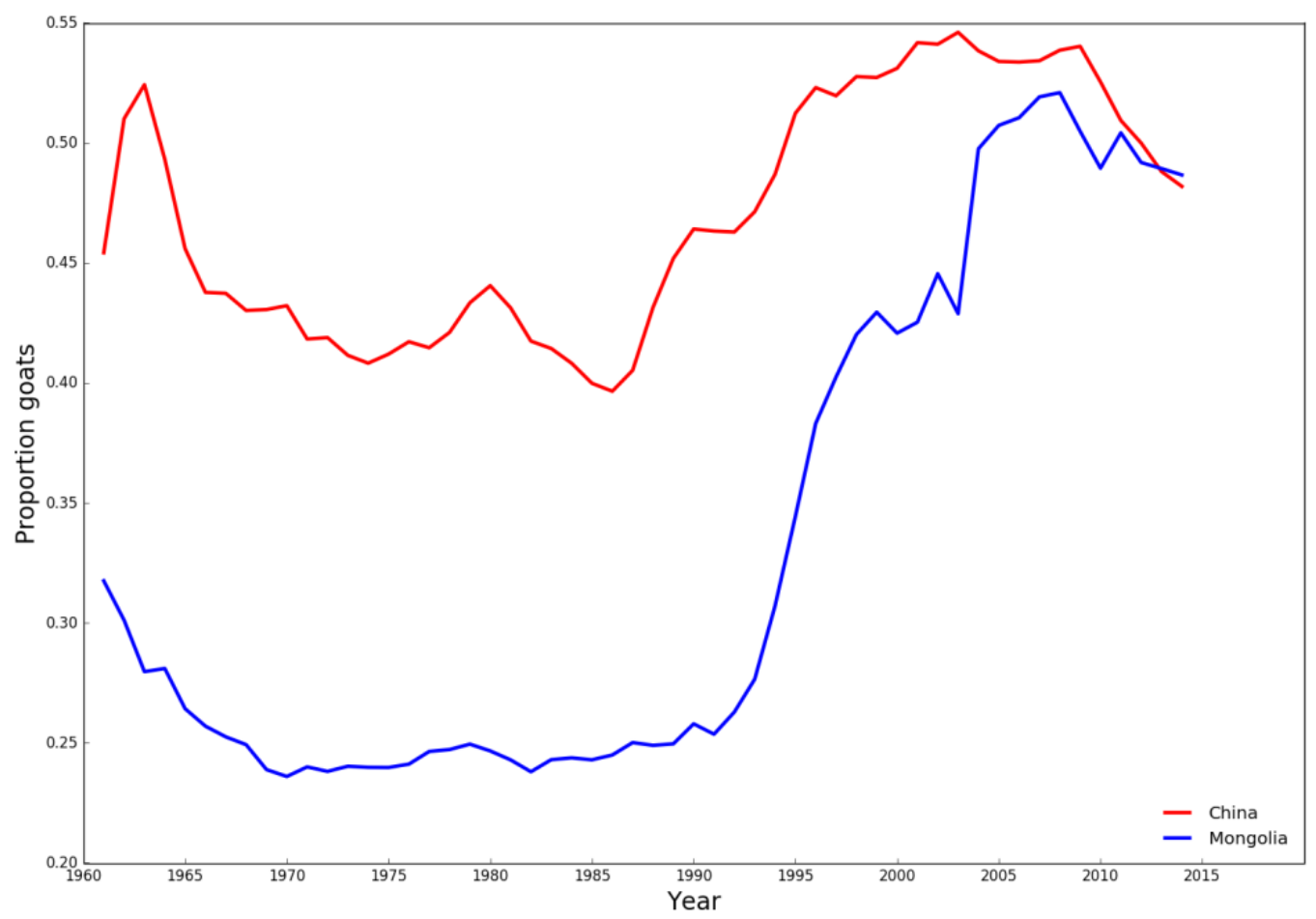

Figure 2. Temporal trends in proportion of goats to total number of sheep and goats. Source: FAOSTAT (http://faostat.fao.org/). 


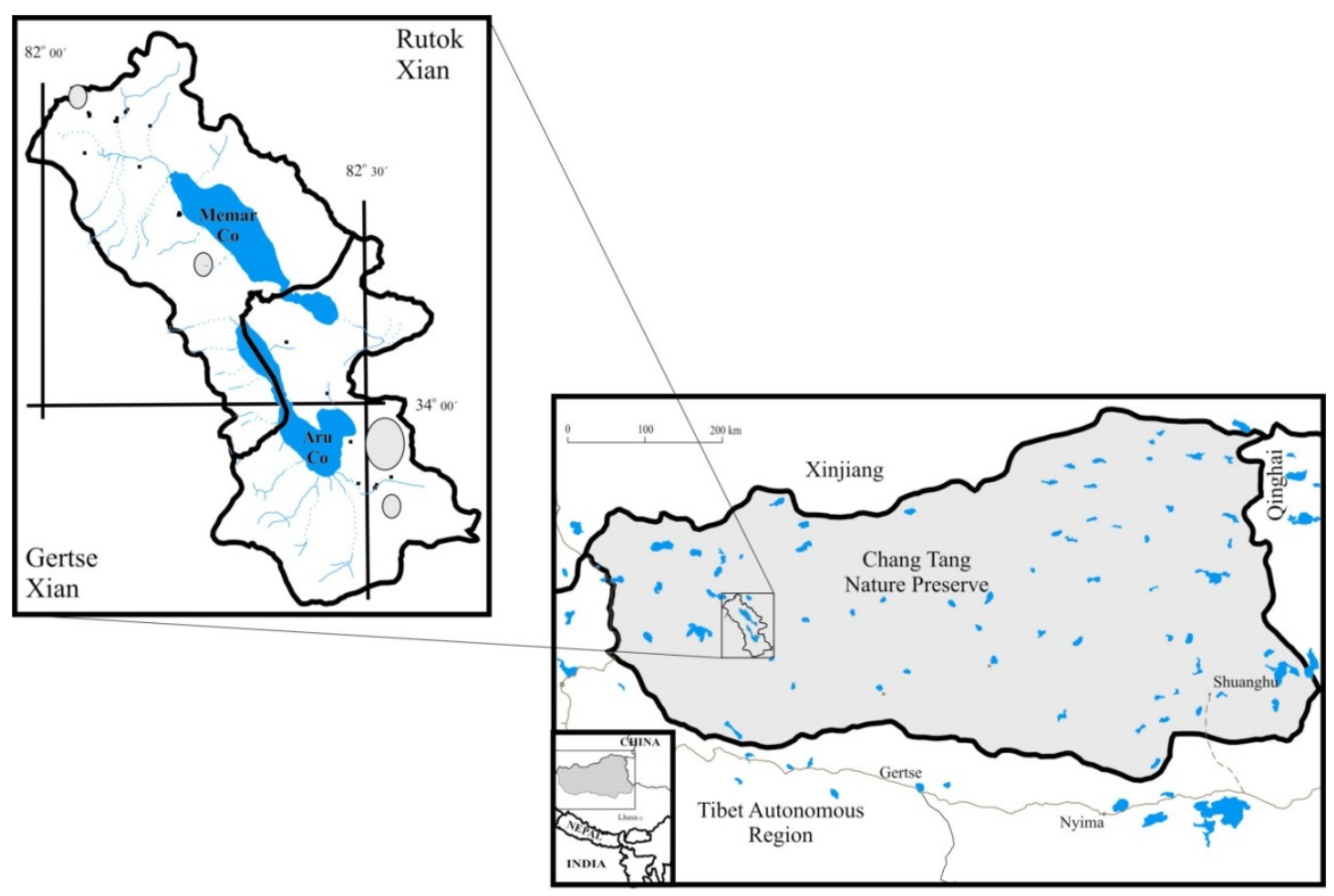

Figure 3. The ca 2,300- $\mathrm{km}^{2}$ Aru Basin study area within the ca $300,000 \mathrm{~km}^{2}$ Chang Tang Nature Reserve (adopted from Næss, 2003). Two administrative districts divide the basin's grazing areas: Gertse and Rutok Xian. 


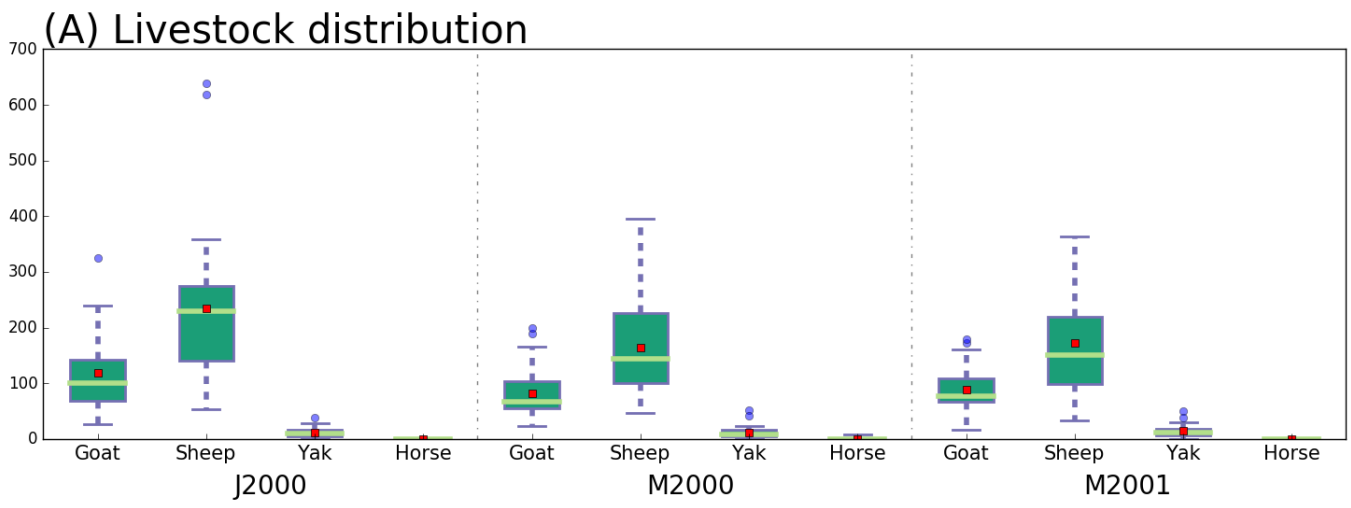

(B) Proportion female goats
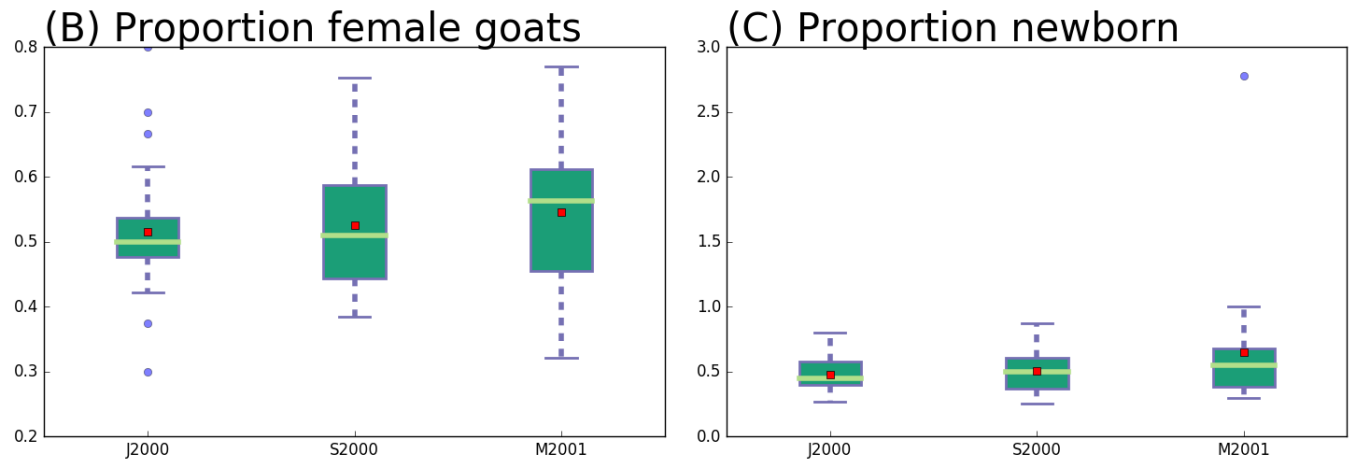

Figure 4. Descriptive statistics of livestock in the Aru basin for the three periods of fieldwork undertaken ( $n=34$ for June 2000, $n=28$ for September 2000 and $n=22$ for May 2001). (A) Distribution of goats, sheep, yaks and horses; (B) Proportion of female goats to adult goats; and $(\mathrm{C})$ Proportion of newborn goats to female goats. Horizontal lines in boxes show median values while red squares show mean values. 


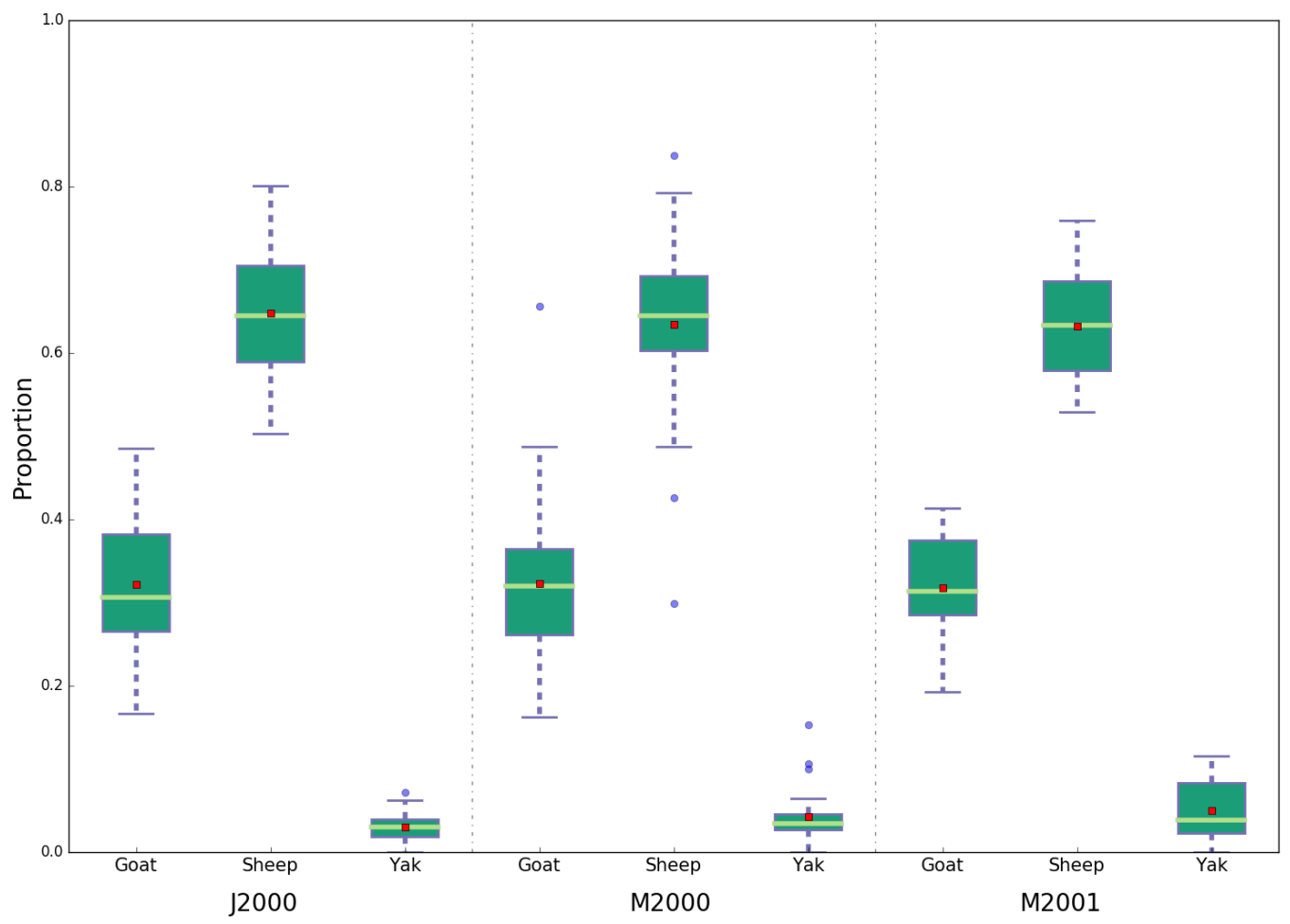

Figure 5. Proportion of goats, sheep and yaks in livestock herds in the Aru Basin. Horses are not shown due to the low prevalence (see Fig. 2), but are included in total herd size. Horizontal lines in boxes show median values while red squares show mean values. 


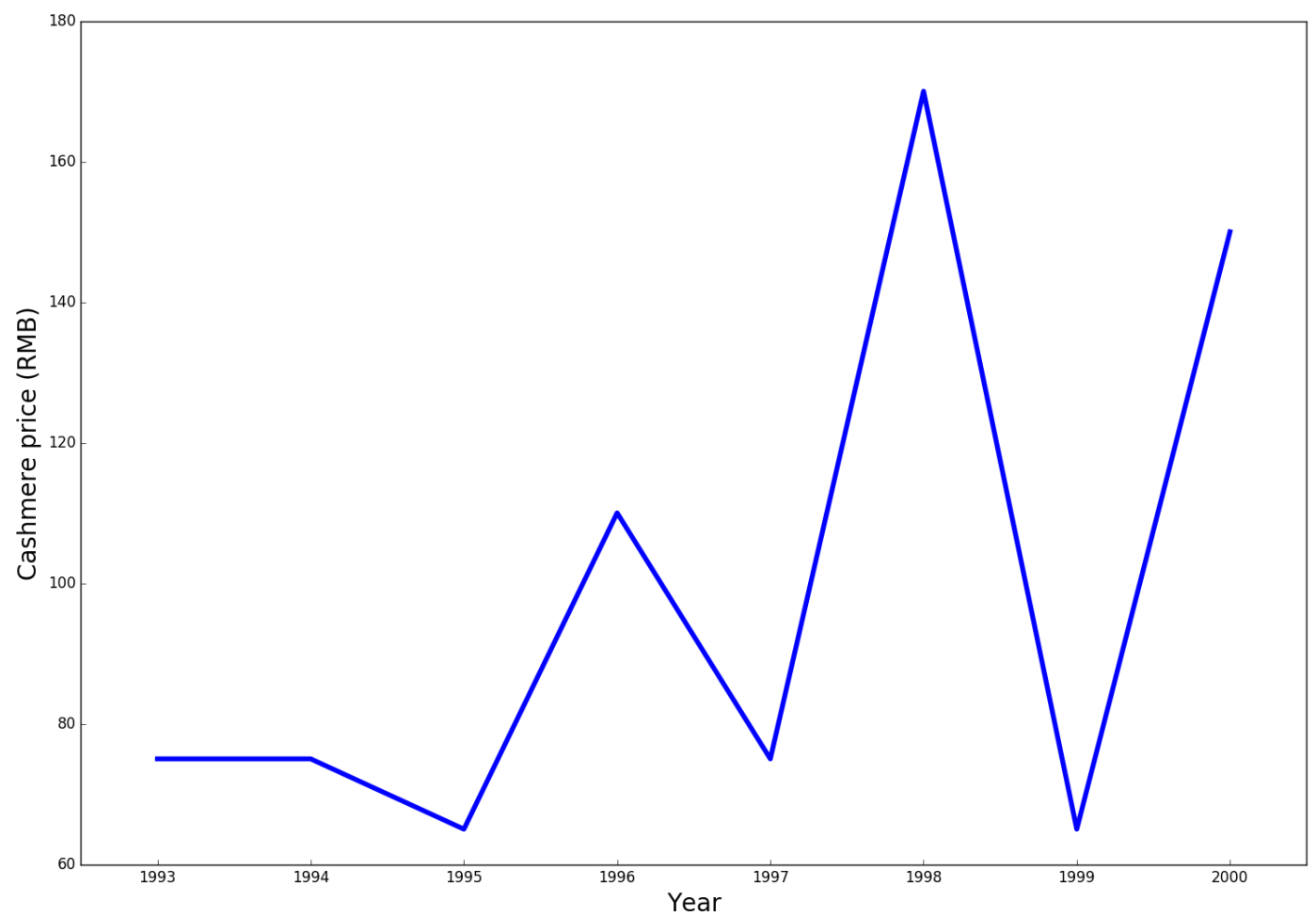

Figure 6. Temporal trends in cashmere wool prices 1993-2000 as reported by the Aru nomads. ${ }^{16}$ Prices are RMB per jin. Linear regression showed an increase in price over year, but this increase was not statistically significant (see Næss and Bårdsen 2016). Source: Table 3 in Næss et al. (2004).

\footnotetext{
${ }^{16}$ It must be kept in mind that these prices were given from the memory of some of the nomads, and they were not sure if they remembered them right, i.e. if they gave the right price for the right year. However, the general argument that prices fluctuate still holds true.
} 


\section{TABLES}

Table 1: Showing the difference between governmental set quotas and actual yield for sheep and goats in the Aru basin. Numbers are given as averages.

\begin{tabular}{lll}
\hline & Quotas & Actual Yield \\
\hline Sheep & & \\
Male & $1 \mathrm{~kg}$ & $0.75 \mathrm{~kg}$ \\
Female & $1 \mathrm{~kg}$ & $0.5 \mathrm{~kg}$ \\
Goats & & \\
Male & $0.25 \mathrm{~kg}$ & $0.15 \mathrm{~kg}$ \\
Female & $0.25 \mathrm{~kg}$ & $0.10 \mathrm{~kg}$ \\
\hline
\end{tabular}

Table 2. Showing the average proportions of female animals relative to total number of adult animals in goat and sheep herds.

\begin{tabular}{|c|c|c|c|c|c|c|c|c|}
\hline & \multicolumn{4}{|c|}{ Goat } & \multicolumn{4}{|c|}{ Sheep } \\
\hline & Mean & SE & Range & $n$ & Mean & SE & Range & $n$ \\
\hline \multicolumn{9}{|l|}{ Rutok xian } \\
\hline June 2000 & 0.52 & 0.016 & $(0.30,0.80)$ & $33^{\mathrm{a}}$ & 0.49 & 0.014 & $(0.32,0.82)$ & 34 \\
\hline September-October 2000 & 0.49 & 0.016 & $(0.38,0.70)$ & 15 & 0.45 & 0.024 & $(0.26,0.59)$ & 15 \\
\hline May 2001 & 0.51 & 0.034 & $(0.32,0.71)$ & 12 & 0.45 & 0.028 & $(0.29,0.59)$ & 12 \\
\hline \multicolumn{9}{|l|}{ Gertse xian } \\
\hline September-October 2000 & 0.57 & 0.025 & $(0.42,0.75)$ & 13 & 0.52 & 0.015 & $(0.45,0.63)$ & 13 \\
\hline May 2001 & 0.58 & 0.032 & $(0.38,0.77)$ & 10 & 0.53 & 0.027 & $(0.35,0.67)$ & 10 \\
\hline
\end{tabular}

${ }^{a}$ One household had no information about female goats. 